\title{
Evaluation of the impact of two types of steel fibers (SE), mono and 3D, on concrete properties, when added isolated or blended
}

\section{Avaliação do impacto de dois tipos de fibras de aço, simples e espaciais, nas propriedades do concreto, quando inseridas separadamente ou de forma combinada}
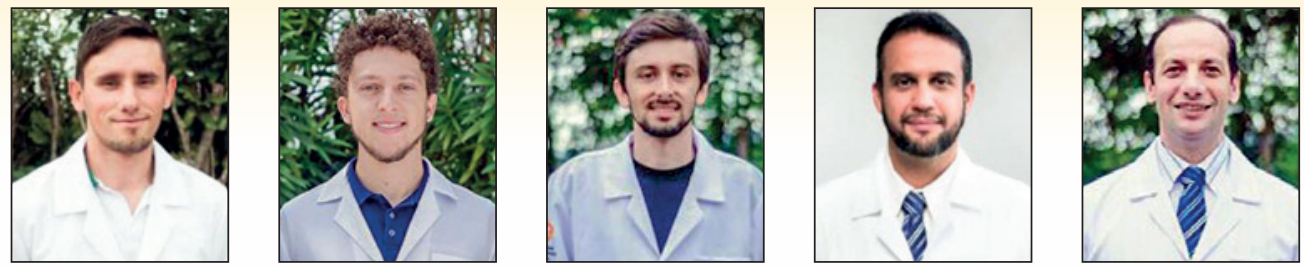

A. L. BAUER a andersonbauer1995@gmail.com https://orcid.org/0000-0002-7633-618X

$\begin{array}{r}\text { H. EHRENBRING a } \\ \text { hzamis@unisinos.br }\end{array}$
https://orcid.org/0000-0002-0339-9825
https://orcid.org/0000-0002-8810-460X
$\begin{array}{r}\text { D. SCHNEIDER a } \\ \text { diegosch@unisinos.br }\end{array}$

U. C. M. QUININO

uquinino@unisinos.br https://orcid.org/0000-0002-6488-9828

B. TUTIKIAN a

bftutikian@unisinos.br https://orcid.org/0000-0003-1319-0547

\begin{abstract}
The brittle behavior of concrete can be compensated by the addition of reinforcements, providing benefits such as improved crack control, residual strength and increased flexural strength. It is usual to apply mono fibers to concrete, but their positioning in the matrix may not be homogeneous, consequently increasing the susceptibility to fracture planes with fewer reinforcements. This study aimed to evaluate the use and behavior of simple (mono) and space (3D) steel fibers (SE), in order to achieve a more homogeneous mixture, increase the effectiveness of fibers in restricting cracks and improve mechanical properties. The fresh-state was assessed through slump and VeBe tests, whereas the hardened-state tests comprised axial compressive strength, flexural strength and the flexural toughness factor. The volume content of simple and space fibers varied from 0 to $0.93 \%$. Based on the results, it can be stated that space and simple fiber contents improved rheological and mechanical properties of the composite in isolated $(0.29 \%)$ and hybrid $(0.64 \%)$ combinations, since their overall performance exceeded the other mixtures'. However, space fibers caused considerable workability losses compared to the conventional concrete, hindering its casting and harming its hardened-state properties.
\end{abstract}

Keywords: fiber-reinforced concrete, space fiber, simple fibers, hybrid mixtures.

\section{Resumo}

O comportamento frágil de concretos pode ser compensado com a inserção de reforços, proporcionando benefícios no que tange ao controle de fissuração, ganho de tenacidade, aumento da resistência à tração, entre outros. Comumente, aplicam-se fibras isoladas em concretos, porém o seu posicionamento na matriz pode não ser homogêneo e, consequentemente, facilita-se o surgimento de planos de ruptura com baixo número de reforços. Assim, o trabalho em questão teve como objetivo avaliar a aplicação e comportamento de fibras simples e espaciais em aço, a fim de proporcionar uma mistura mais homogênea, aumentar a área de atuação da fibra na contenção de fissuras e melhorias nas propriedades mecânicas. Os ensaios no estado fresco foram de consistência do compósito, por meio do abatimento do tronco de cone e do VeBe, e, no estado endurecido, avaliou-se a resistência à compressão axial, resistência à tração na flexão e o fator de tenacidade. Variou-se o teor de adição das fibras uni (simples) e espaciais, em volume, de 0 até $0,93 \%$. Com base nos resultados, pode-se afirmar que os teores de fibras espaciais e simples foram benéficos às propriedades reológicas e mecânicas do compósito na combinação isolada $(0,29 \%)$ e híbrida $(0,64 \%)$, dado que demonstraram desempenho geral superior às demais misturas. Entretanto, as fibras espaciais acarretam consideráveis perdas da trabalhabilidade, comparado ao concreto tradicional sem fibras, dificultando o seu lançamento e, consequentemente, propriedades no estado endurecido.

Palavras-chave: concreto reforçado com fibras, fibra espacial, fibras simples, misturas híbridas.

Unisinos, itt Performance, São Leopoldo, RS, Brazil.

Received: 14 Aug 2018 • Accepted: 30 Sep $2019 \cdot$ Available Online: 26 May 2020

This is an open-access article distributed under the terms of the Creative Commons Attribution License 


\section{Introduction}

Concrete is a material with sensitive behavior that relies on other components that can change its failure mode [1]. Steel reinforcements are then specified to increase tensile strength, even though this type of stress acts in a concentrated way, which is not effective to mitigate localized cracks, impacting the durability of the system. The addition of fibers to concrete aims to amend these deficiencies, since it is supposed to make the material isotropic, improving its performance when subjected to mechanical actions and increasing the area that fends off cracking [2].

According to Ibrahim et al. [3], the use of SE fibers as concrete matrix reinforcement brings about a series of benefits to its hardened state, such as the increase of load-bearing capacity and fracture strength, while improving the control of cracks, which in turn extends the composite's life span. As for fresh state, the fibers themselves form an internal mesh that hinders the movement of the coarse aggregates within the mixture. This action may impair the processes of casting the composite in the molds, as microfibers make it harder for coarse aggregates to homogenize with the other materials $[4,5]$. It should be noted that the fiber reinforcement acts as a stress transfer bridge that limits the appearance of fracture planes and restrain crack propagation, hence increasing tensile failure stress and causing the composite to change from a state of brittleness to one of pseudo-ductility [6]. The current literature widely covers the advantage of using numerous types of mono-fibers [7, 8, 9], which are distributed separately within the matrix, whereas each one acts in a single direction that is typified by the mobility of reinforcements inside the matrix. Researchers in the field of aerospace engineering have developed structural sets capable of acting in multiple directions, as to increase the mechanical strength of other composites [10,11], although such reinforcement has not been added to cement matrices yet. Even if the identified results are interesting, there is still a gap concerning the performance of concrete reinforced with space fibers, which are marked by a specific setting that is structured with simple fibers acting in 3 directions (3D). It is expected that this new reinforcement model may increase the number and/or efficiency of fibers in the fracture plane, since their arrangement gets better controlled and the set is theoretically more effective. Therefore, it can be assured that the fracture plane will tend to be intercepted by space fibers no matter the placement, since the set has rigid fiber bindings that are orthogonal to each other and act as 3D reinforcements, increasing the strength of the matrix fracture plane.

Studies on the use of 2D fibers were developed as well, exemplified by the textile-reinforced concrete [12, 13], which brings along a series of advantages compared to conventional and reinforced concretes. Some of these advantages are great tensile and compressive performances, high durability, owing to the matrix having low water-cement ratio $(<0.30)$, and the fibers used do not require corrosion protection, allowing for a reduction of the weight of structures [14]. Another benefit of these composites is the possibility of subjecting the pieces to geometric forming.

In order to achieve even higher gains, two or more fibers can be blended in a same matrix to enhance the composite's performance. This fiber blend is also known as hybridization. The types of material of each fiber and their geometry are often varied. However, it is still necessary to figure out the best way to blend the effects of fibers that act in different directions, to reach maximum interaction and so achieve optimal performance [2, 15].

Quinino [2] explains that the hybridization of polypropylene (PP) and SE fibers, working together and in proper amounts, improves the performance of the matrix, as PP microfibers hinder the formation of microcracks and can even restrict likely differential displacements that take place within the composite during formation and propagation of cracks, while SE macrofibers stay in charge of "sewing" cracks up, hindering their opening and extension.

Banthia and Sappakittipakorn [16] also reached promising results when they evaluated the hybridization of matrices with two types of corrugated SE fibers, varying only the aspect ratio, fixing fiber length, demonstrating positive effects on the mechanical properties of concrete.

For this purpose, the experimental procedure was designed to evaluate the influence on fresh state and mechanical properties of cement matrices reinforced with simple and space fibers in varied amounts, isolated and with fiber hybridization.

\section{Experimental procedure}

The experimental procedure regards the analysis of the physical behavior of a conventional concrete when reinforced with simple

\section{Table 1}

Steel fiber content in the mixture of each composite of this study

\begin{tabular}{|c|c|c|c|c|c|c|}
\hline \multirow{3}{*}{ Mixture } & \multirow{2}{*}{\multicolumn{2}{|c|}{ Fiber content }} & \multicolumn{4}{|c|}{ Fiber type } \\
\hline & & & \multicolumn{2}{|c|}{ Simple } & \multicolumn{2}{|c|}{ Space } \\
\hline & $\mathrm{kg} / \mathrm{m}^{3}$ & $\%$ in volume & $\mathrm{kg} / \mathrm{m}^{3}$ & $\%$ in volume & $\mathrm{kg} / \mathrm{m}^{3}$ & $\%$ in volume \\
\hline MR & 0 & $0.00 \%$ & 0 & $0.00 \%$ & 0 & $0.00 \%$ \\
\hline M1 & 10 & $0.14 \%$ & 10 & $0.14 \%$ & 0 & $0.00 \%$ \\
\hline M2 & 20 & $0.29 \%$ & 20 & $0.29 \%$ & 0 & $0.00 \%$ \\
\hline M3 & 40 & $0.52 \%$ & 10 & $0.14 \%$ & 30 & $0.38 \%$ \\
\hline M4 & 50 & $0.67 \%$ & 20 & $0.29 \%$ & 30 & $0.38 \%$ \\
\hline M5 & 60 & $0.78 \%$ & 10 & $0.14 \%$ & 50 & $0.64 \%$ \\
\hline M6 & 70 & $0.93 \%$ & 20 & $0.29 \%$ & 50 & $0.64 \%$ \\
\hline M7 & 30 & $0.38 \%$ & 0 & $0.00 \%$ & 30 & $0.38 \%$ \\
\hline M8 & 50 & $0.64 \%$ & 0 & $0.00 \%$ & 50 & $0.64 \%$ \\
\hline
\end{tabular}




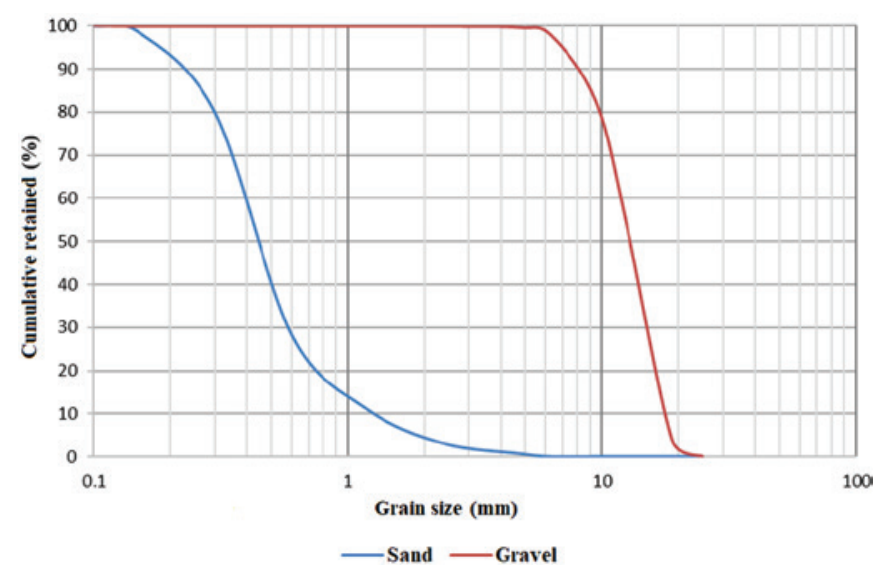

Figure 1

Particle-size distribution of fine and coarse aggregates

and space SE fibers, forming a fiber reinforced concrete (FRC). The composites were crafted with 25-MPa conventional concrete dosed as per the method of Tutikian and Helene (IBRACON Method) [17]. So, 9 different mixtures were molded, one for the unreinforced reference concrete (MR) and the other 8 were reinforced with fibers (M1 - M8). The fresh-state characteristics were evaluated through the slump and $\mathrm{VeBe}$ methods. The mechanical properties under analysis comprised axial compressive strength, flexural strength and flexural toughness, all of which were tested at 28 days. Table 1 presents the SE fiber content of each mixture in volume with mass compensation.

The fiber contents were chosen based on usual average consumptions that range from 10 to $70 \mathrm{~kg} / \mathrm{m}^{3}$, in accordance with Banthia and Sappakittipakorn [16], Boulekbache et al. [18] and Quinino [2] Mixtures M3, M4, M5 and M6 were subjected to fiber hybridization with varied contents of simple and space fibers. Both simple and space fibers were made of SE and had hooked ends that were able to improve the performance of the composite by reducing the likelihood of the reinforcement being expelled from the cement matrix as tensile stresses increase. The following items cover the materials and methods that were used along this research.

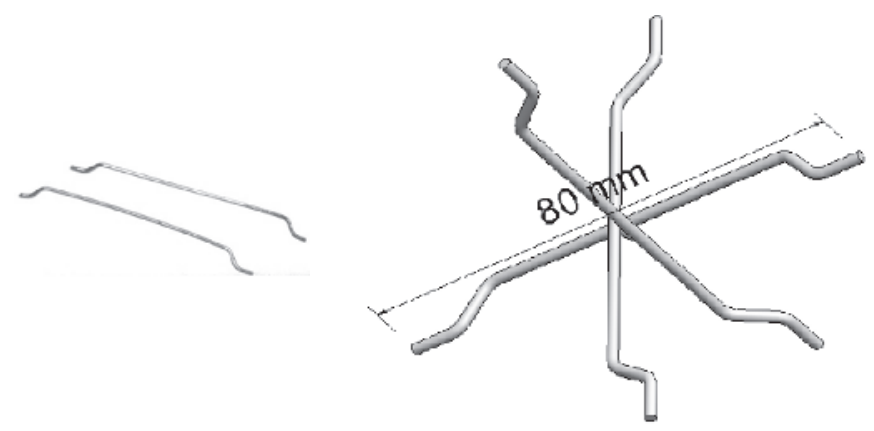

(a)

(b)

Figure 2

Shape of (a) simple and (b) space fibers

\subsection{Materials used}

All mixtures were made with type-III Portland cement, specified by ASM C150:2018 [19]. The density of the material was $3.04 \mathrm{~g} / \mathrm{cm}^{3}$, with surface area of $4936 \mathrm{~cm}^{2} / \mathrm{g}$. The quartzous fine aggregate used had maximum grain size of $4.8 \mathrm{~mm}$ and fineness modulus of 2.22. The specific gravity of this material was assessed as per ASTM C128:2015 [20] and yielded the value of $2.63 \mathrm{~g} / \mathrm{cm}^{3}$. Regarding unit weight, the value of 1.54 $\mathrm{g} / \mathrm{cm}^{3}$ was identified by following the procedures prescribed by ASTM C29:2017 [21]. As for the natural coarse aggregate, its maximum size and fineness modulus were $19.0 \mathrm{~mm}$ and 6.86 respectively. The specific gravity was equals $2.69 \mathrm{~g} / \mathrm{cm}^{3}$, according to methods of ASTM C127:2015 [22]. The unit weight of gravel was determined in accordance with ASTM C29:2017 [2017], resulting in $1.45 \mathrm{~g} / \mathrm{cm}^{3}$.

The natural aggregates were graded under the parameters set by ASTM C33:2018 [23] and ASTM C136:2014 [24]. Figure 1 then depicts the particle-size distribution of fine and coarse aggregates. Simple fibers (Figure 2-a) with length of $60 \mathrm{~mm}$ were adopted due to their compatibility with the coarse aggregate, hence allowing the fiber to perform well as a structural reinforcement for concrete [25]. Moreover, these fibers had diameter of $0.75 \mathrm{~mm}$, which yields an aspect ratio of 80 . The space fibers (Figure 2-b) had length of $80 \mathrm{~mm}$ and diameter of $1.8 \mathrm{~mm}$, which means an aspect ratio of 44 . The simple fiber had strength of $1000 \mathrm{MPa}$, just like the filaments used in the production of space fibers. It should be noted that space fibers are new reinforcements with specific arrangements, which, for the purpose of this study, were manually crafted to allow their assessment, since they have not been made available for purchase in the market yet. Hence, 3 fiber were used per arrangement, interconnected with solder and oriented at $90^{\circ}$. This orthogonality between fibers remained during the operations of concrete mixing, casting and consolidation. The dimensions of these fibers had to be greater than those of simple fibers in order to achieve the proper soldering. Nevertheless, the filaments applied to the space fibers were type $A$ and class I (A-I), according to definitions of ABNT NBR 15530:2007 [26]. The technical naming used in this study to distinguish the fibers was "simple" and "space", as to discriminate the way each type of fiber acts.

\subsection{Dosing method and mixing process}

The reference concrete was dosed with the intent of achieving compressive strength of $25 \mathrm{MPa}$, adopting cement content of $280 \mathrm{~kg} /$ $\mathrm{m}^{3}$ and water-cement ratio of 0.66 . The reference mix ratio was 1 : 2.51: 3.43 (cement: sand: gravel). The mixtures had the same base cement matrix, changing the type of reinforcement in use. The fiber content was determined according to the mass of reinforcements per cubic meter, ranging from 10 to $70 \mathrm{~kg} / \mathrm{m}^{3}$. The slump of the reference matrix was fixed to reach class $\mathrm{S} 160(160 \leq \mathrm{s} \leq 220 \mathrm{~mm})$ and plastic workability for the VeBe test, and just the same for FRC. Moreover, during the homogenization of materials, the formation of lumps, that is, localized agglomeration of fibers, could not be noted. Table 2 presents the parameters for classifying the workability of the cement matrices used as reference in this study. 
Table 2

Workability classified by the VeBe test

\begin{tabular}{ccc}
\hline Classification & $\begin{array}{c}\text { Slump } \\
(\mathbf{m m})\end{array}$ & $\begin{array}{c}\text { VeBe } \\
(\mathbf{s})\end{array}$ \\
\hline $\begin{array}{c}\text { Extremely dry } \\
\text { Very stiff }\end{array}$ & - & 32 to 18 \\
(maintains shape) & - & 18 to 10 \\
Stiff & 0 to 25 & 10 to 5 \\
Stiff plastic & 25 to 75 & 5 to 3 \\
Plastic & 75 to 125 & 3 to 0 \\
Very plastic & 125 to 190 & - \\
\hline
\end{tabular}

Source: Adapted from ACl 21 1.R3-02 [30]

\subsection{Specimen produce and curing}

For the 28-day compressive strength test, two cylindrical specimens were molded per mixture, with $100 \mathrm{~mm}$ of diameter and 200 $\mathrm{mm}$ of height, as per specifications of ASTM C192:2016 [27]. Then, the samples remained for 24 hours at room temperature, covered with a glass plate. After this period, they were unmolded and stored in a curing chamber with temperature of $21 \pm 2^{\circ} \mathrm{C}$ and humidity of $95 \pm 3 \%$, remaining there until they had reached the testing age. The dimensions of the flexural strength and flexural toughness test samples followed the recommendations of JSCE-SF4:1984 [28], so two prismatic specimens were molded with dimensions of $150 \times 150 \times 500 \mathrm{~mm}$. The molding process was conducted under recommendations of ASTM C192:2016 [27]. Then, the curing procedure followed the same requirements as the cylindrical specimens.

\subsection{Fresh-state concrete}

Concrete workability was analyzed by slump and dynamic $\mathrm{VeBe}$ tests. The first is guided by ASTM C143:2015 [29], while the latter is specified by ACI 211.3R-02:2009 [30] and DNIT 064:2004 [31].

\subsection{Hardened concrete}

\subsubsection{Compressive strength}

The simple compressive strength was assessed under recommendations of ASTM C39:2018 [32]. The specimens were ground to improve the distribution of loads during the test, being subjected to testing in a hydraulic press with capacity of $2000 \mathrm{kN}$. Load was applied with a velocity of $0.45 \pm 0.15 \mathrm{MPa} / \mathrm{s}$ until failure. The specimens were tested at 28 days, 2 specimens per mixture, yielding a total of 18 samples.

\subsubsection{Equivalent flexural strength and flexural toughness factor}

The flexural strength and flexural toughness tests abided by JSCESF4:1984 [28]. For the first, the test setting consists of laying the beam over two punches and then apply load through two other punches placed on top of the beam, at the mid one-third of the span, as depicted in Figure 3. The method specified by the standard states that the test span must be thrice the height of the specimen, so the dimensions were $450 \mathrm{~mm}$ of length span, $150 \mathrm{~mm}$ of height and $150 \mathrm{~mm}$ of width. A 2000-kN Shimadzu press was used, and the load was applied by prescribed displacement, at 28 days, two specimens per mixture, leading to a total of 18 samples.

\section{Results and discussions}

\subsection{Fresh-state Properties}

Table 3 shows the fresh-state concrete test results. It can be noted
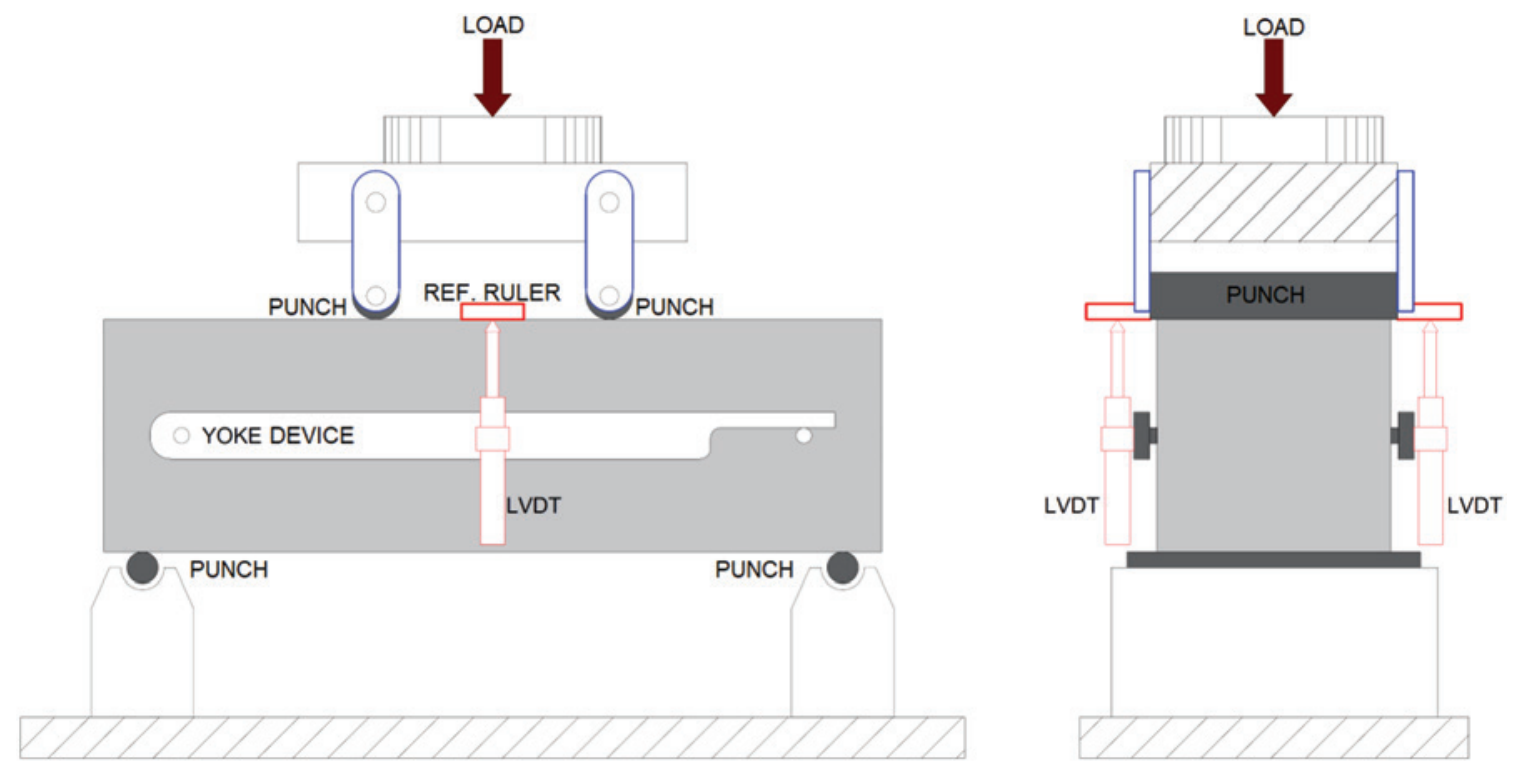

\section{Figure 3}

Test apparatus - four-point bending

Source: Adapted by the authors from JSCE-SF4 (1984) 
Table 3

Fresh-state results of the mixtures

\begin{tabular}{|c|c|c|c|c|c|c|}
\hline \multirow[t]{2}{*}{ Mixture } & \multicolumn{2}{|c|}{$\begin{array}{c}\text { Steel fiber } \\
\left(\mathrm{kg} / \mathrm{m}^{3}\right)\end{array}$} & \multirow{2}{*}{$\begin{array}{c}\text { Total } \\
\left(\mathrm{kg} / \mathrm{m}^{3}\right)\end{array}$} & \multirow[t]{2}{*}{ Blended } & \multirow{2}{*}{$\begin{array}{l}\text { Slump } \\
(\mathrm{mm})\end{array}$} & \multirow{2}{*}{$\begin{array}{c}\mathrm{VeBe} \\
(\mathrm{s})\end{array}$} \\
\hline & Space & Simple & & & & \\
\hline MR & 0 & 0 & 0 & - & 170 & 1.5 \\
\hline M1 & 0 & 10 & 10 & $\mathrm{E} 0+\mathrm{M} 10$ & 170 & 1.4 \\
\hline M2 & 0 & 20 & 20 & $\mathrm{E} 0+\mathrm{M} 20$ & 130 & 1.6 \\
\hline M3 & 30 & 10 & 40 & $\mathrm{E} 30+\mathrm{M} 10$ & 20 & 5.31 \\
\hline M4 & 30 & 20 & 50 & $\mathrm{E} 30+\mathrm{M} 20$ & 40 & 3.19 \\
\hline M5 & 50 & 10 & 60 & $\mathrm{E} 50+\mathrm{M} 10$ & 20 & 4.56 \\
\hline M6 & 50 & 20 & 70 & $\mathrm{E} 50+\mathrm{M} 20$ & 20 & 4.63 \\
\hline M7 & 30 & 0 & 30 & E30+MO & 50 & 4.32 \\
\hline M8 & 50 & 0 & 50 & $\mathrm{E} 50+\mathrm{MO}$ & 20 & 4.34 \\
\hline
\end{tabular}

that the addition of fibers reduced the workability of the composite, and the values were consistent with those found by Abbass et al. [33]. Akcay and Tasdemir [34] and Banthia et al. [15]. Velasco [35] stated that fiber-reinforced concrete tends to lose workability and fluidity, a loss that becomes clearer as fiber content increases. This workability loss is even more evident for mixtures reinforced with space fibers, as the VeBe test values increased by $184.7 \%$ and $200.7 \%$ for mixtures with $30 \mathrm{~kg} / \mathrm{m}^{3}$ and $50 \mathrm{~kg} / \mathrm{m}^{3}$ of space fibers respectively. The rates show that space fibers exceed the shear strength of fresh-state mixtures, hindering particle dispersion and raising the need for alternatives that promote fluidity for handling. Under these circumstances, it is recommended to use mechanical consolidation with proper devices [36], or even change the composition of the cement matrix. Such change concerns the increase of mortar content, which increases the mobility of materials added to concrete, by means of lubrication, reducing internal friction between particles, hence allowing the proper consolidation that fiberreinforced concrete needs.

This behavior can be justified by the low mobility of space fiberreinforced composites, since these fibers are formed by a set of three simply interconnected fibers, so they end up requiring more

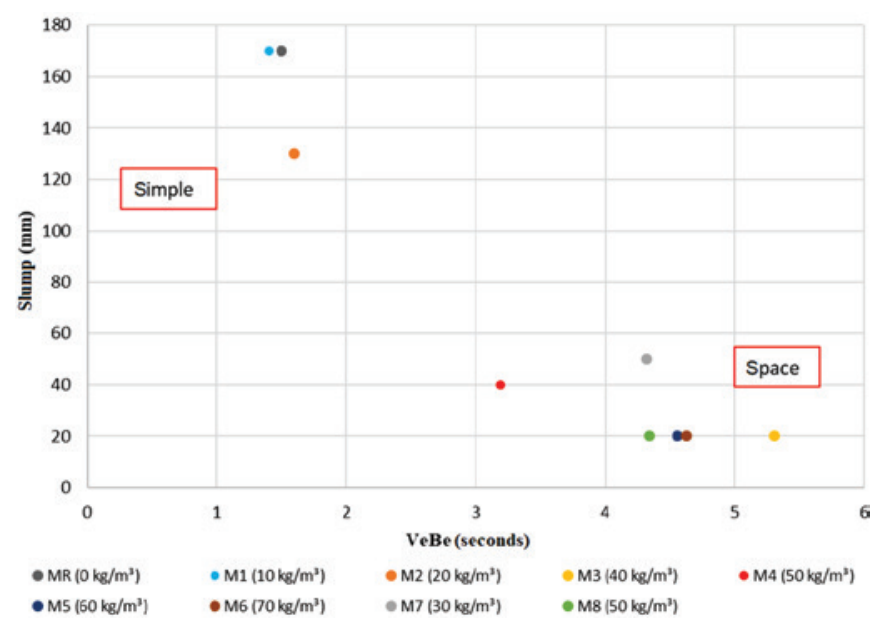

Figure 4

Relation between slump and VeBe tests energy to be moved than simple fibers. This leads to a structured mixture that limits the fluidity of the matrix.

Figure 4 compares the fresh-state concrete test results and shows that space fibers cause considerable influence on the workability of the matrix as there was an average reduction of $174 \%$ based on the matrices studied. This behavior was observed in the VeBe test for mixtures with $30 \mathrm{~kg} / \mathrm{m}^{3}$ and $50 \mathrm{~kg} / \mathrm{m}^{3}$ of space fibers. Moderate decreases were also identified when simple fibers were hybridized. So, among the mixtures with space fibers, matrix M4 yielded the best results, while matrix $\mathrm{M} 3$, which contained $40 \mathrm{~kg} / \mathrm{m}^{3}$, attained the worst results due to its limited consolidation. Lastly, mixtures M8, M5 and M6, which contained $50 \mathrm{~kg} / \mathrm{m}^{3}$ of space fibers, behaved similarly with respect to each other.

\subsection{Compressive strength}

Table 4 presents the potential compressive strength of the mixtures. These values correspond to the highest strength attained by each composite and are followed by their respective standard deviation. The tests were performed at 28 days, along with the prismatic specimens that were tested for flexural strength.

It is noteworthy that none of the fiber-reinforced mixtures reached values that exceed the reference, indicating that the addition of these elements did not contribute to the increase of compressive strength, agreeing with [33, 34, 36, 37]. Additionally, the standard deviation of fiber-reinforced samples was higher than that of the

\section{Table 4}

Potential compressive strength of each composite

\begin{tabular}{ccc}
\hline Mixture & $\begin{array}{c}\text { Fiber content } \\
\left(\mathbf{k g} / \mathbf{m}^{3}\right)\end{array}$ & $\begin{array}{c}\mathbf{f}_{\mathrm{c}} \\
(\mathbf{M P a})\end{array}$ \\
\hline MR & 0 & $36.4 \pm 2.5$ \\
M1 & 10 & $32.3 \pm 3.1$ \\
M2 & 20 & $30.2 \pm 2.8$ \\
M3 & 40 & $33.1 \pm 3.3$ \\
M4 & 50 & $35.4 \pm 3.5$ \\
M5 & 60 & $31.4 \pm 2.9$ \\
M6 & 70 & $29.7 \pm 3.2$ \\
M7 & 30 & $30.6 \pm 1.9$ \\
M8 & 50 & $26.9 \pm 2.6$ \\
\hline
\end{tabular}




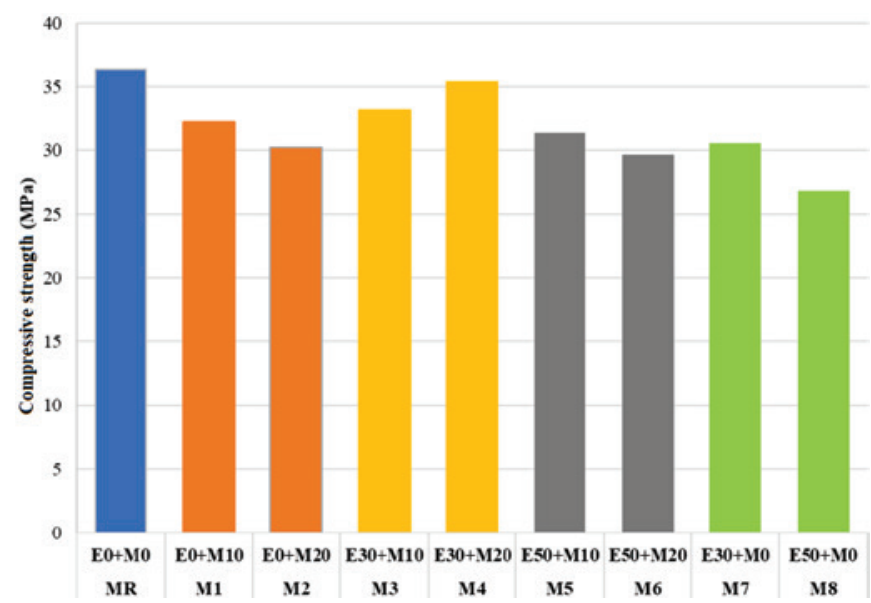

Figure 5

Potential compressive strength

reference matrix due to the instability that is inherent to this casting process. The addition of fibers caused average decreases of $14.3 \%$. Analyzing non hybridized mixtures, the fibers decreased compressive strength by up to $17.0 \%$ for mixtures with simple fibers, while mixtures with space fibers reached higher decreases, ranging from $15.9 \%$ to $26.1 \%$, which represent matrices $\mathrm{M} 7$ and M8 respectively. Hybridization lessened these decreases though, since mixtures $\mathrm{M} 3$ and $\mathrm{M} 4$, with $30 \mathrm{~kg} / \mathrm{m}^{3}$ of space fibers, yielded decreases of $8.8 \%$ and $2.5 \%$ respectively. On the other hand, mixtures M5 and M6, which contained $50 \mathrm{~kg} / \mathrm{m}^{3}$ of space fibers, reached decreases of $13.7 \%$ and $18.4 \%$ respectively. Mixture M4 performed well in the end, in spite of the hybridized mixtures with $50 \mathrm{~kg} / \mathrm{m}^{3}$ of space fibers, which presented the highest compressive strength losses. The compressive strength results have been plotted in Figure 5.

\subsection{Flexural strength}

Table 5 demonstrates the flexural strength test results. Mixture M6, which contained $70 \mathrm{~kg} / \mathrm{m}^{3}$, yielded the best performance as it achieved a flexural strength gain of $32.3 \%$ compared to the reference concrete. Quinino [2] explains that, the higher the fiber con-
Table 5

Average flexural strength

\begin{tabular}{ccc}
\hline Mixture & $\begin{array}{c}\text { Fiber content } \\
\left(\mathrm{kg} / \mathbf{m}^{3}\right)\end{array}$ & $\begin{array}{c}\mathbf{f}_{f} \\
(\mathbf{M P a})\end{array}$ \\
\hline MR & 0 & $3.03 \pm 0.12$ \\
M1 & 10 & $3.52 \pm 0.09$ \\
M2 & 20 & $3.78 \pm 0.25$ \\
M3 & 40 & $3.54 \pm 0.27$ \\
M4 & 50 & $3.58 \pm 0.17$ \\
M5 & 60 & $3.57 \pm 0.33$ \\
M6 & 70 & $4.01 \pm 0.39$ \\
M7 & 30 & $3.64 \pm 0.37$ \\
M8 & 50 & $3.30 \pm 0.02$ \\
\hline
\end{tabular}

tent, the higher the number of filaments that act directly on the fracture plane as stress transfer bridges, and so, the higher the strength of the matrix. Additionally, mixture M2, whose fiber content was 3.5 times smaller than matrix M6, showed a strength increase of $24.8 \%$, only 7.5 percentage points lower than M6. This suggests that simple SE fibers are more efficient concerning flexural strength, considering that, excluding mixture M6, matrix M2 attained the highest value for flexural strength. The proportional increase of flexural strength with respect to the increase of fiber content was identified by Jang and Yun [38], Khaloo et al. [39], Lee, Cho and Choi [40], Pająk and Ponikiewski [41] and Ehrenbring et al. [42] as well.

The flexural performance was similar for hybrid matrices M3, M4 and $\mathrm{M} 5$, which reached an average $\mathrm{ft}$ of $3.55 \mathrm{MPa}$. Composite M3 stands out among these three as it presented the best value. It should be noted that mixtures $\mathrm{M} 2$ and $\mathrm{M} 7$ reached higher tensile strength values, that is, $7.78 \mathrm{MPa}$ and $3.64 \mathrm{MPa}$ respectively, despite their lower fiber contents. Therefore, the high values of this study have hindered the molding and the distribution of fibers along the samples, affecting the mechanical properties, in accordance with Pacheco et al. [43].

\subsection{Flexural toughness}

The flexural toughness behavior is presented in Table 6 and Figure 6, which was obtained when the composites were subjected

\section{Table 6}

Average toughness values

\begin{tabular}{ccccc}
\hline Mixture & $\begin{array}{c}\text { Fiber content } \\
\left(\mathbf{k g} / \mathbf{m}^{3}\right)\end{array}$ & $\begin{array}{c}\text { Max. load } \\
(\mathbf{k N})\end{array}$ & $\begin{array}{c}\text { FT } \\
(\mathbf{M P a})\end{array}$ & $\begin{array}{c}\text { Efficiency } \\
\left(\mathbf{k g} / \mathbf{m}^{3} . \mathbf{M P a}\right)\end{array}$ \\
\cline { 3 - 5 } MR & 0 & $22.69 \pm 0.87$ & $0.00 \pm 0$ & - \\
M1 & 10 & $26.35 \pm 0.72$ & $0.84 \pm 0.23$ & 11.9 \\
M2 & 20 & $28.32 \pm 1.87$ & $1.30 \pm 0.59$ & 15.4 \\
M3 & 40 & $26.58 \pm 2.02$ & $1.56 \pm 0.16$ & 25.6 \\
M4 & 50 & $26.83 \pm 1.27$ & $2.58 \pm 0.13$ & 19.4 \\
M5 & 60 & $26.75 \pm 2.43$ & $2.47 \pm 0.51$ & 24.3 \\
M6 & 70 & $30.09 \pm 2.81$ & $2.96 \pm 0.63$ & 23.6 \\
M7 & 30 & $27.33 \pm 2.75$ & $1.70 \pm 1.20$ & 17.6 \\
M8 & 50 & $24.69 \pm 0.16$ & $2.26 \pm 0.30$ & 22.1 \\
\hline
\end{tabular}


Evaluation of the impact of two types of steel fibers (SE), mono and 3D, on concrete properties, when added isolated or blended

to the test for determination of equivalent flexural strength. Curves have been depicted for the two specimens of each mixture, and the average results were used for calculation.

After the tests, it was noted that the reference matrix (MR) presented null flexural toughness factor, as expected. This result was reached because the matrix was not reinforced, so its failure was brittle due to its low capacity to deform as more stressed were added along the test. It became evident that the area under the curves increased after the addition of fibers, mainly for samples with higher fiber contents. The hybrid mixtures (M3, M4, M5 and M6) underwent different behaviors, considering that M6 yielded the highest flexural toughness factor, equals 2.96 MPa. In contrast, matrix M3 presented the lowest flexural toughness factor among hybrid mixtures, despite reaching the most efficient factor $\left(25.6 \mathrm{~kg} / \mathrm{m}^{3} . \mathrm{MPa}\right)$.

It was then possible to extract the area below the load-displacement curve to calculate the flexural toughness factor, by means of the formulas of JSCE - SF4:1981 [28]. Table 6 expresses the results for the mixture toughness analysis.

The flexural toughness factor, which relates the amount of energy absorbed by the specimen, just like in studies of Banthia et al. [15], Lee, Cho and Choi [40] and Carrillo, Cárdenas Pulido and Aperador [44], turned out to increase gradually along with the fiber content. Evaluating the improvement of this property with respect to matrix $M 1$, the increases were $54.8 \%$ for mixture M2 and $251.8 \%$ for M6, demonstrating performance gains as fiber content increases. On the other hand, the mixtures with lower fiber contents (M1, M2 and M7) achieved the best yields, since their efficiency exceeds the others', so they require a fewer fibers per strength unit (MPa).

Mixture M4 presented the second-highest flexural toughness factor, but the lowest efficiency among hybrid mixtures $(19.4 \mathrm{~kg} /$ $\mathrm{m}^{3}$.MPA). Mixture M3 stood out as the most efficient. This behavior shows that M3 was able to transfer and absorb stresses more easily, what is related to their placement inside the matrix, supplying a
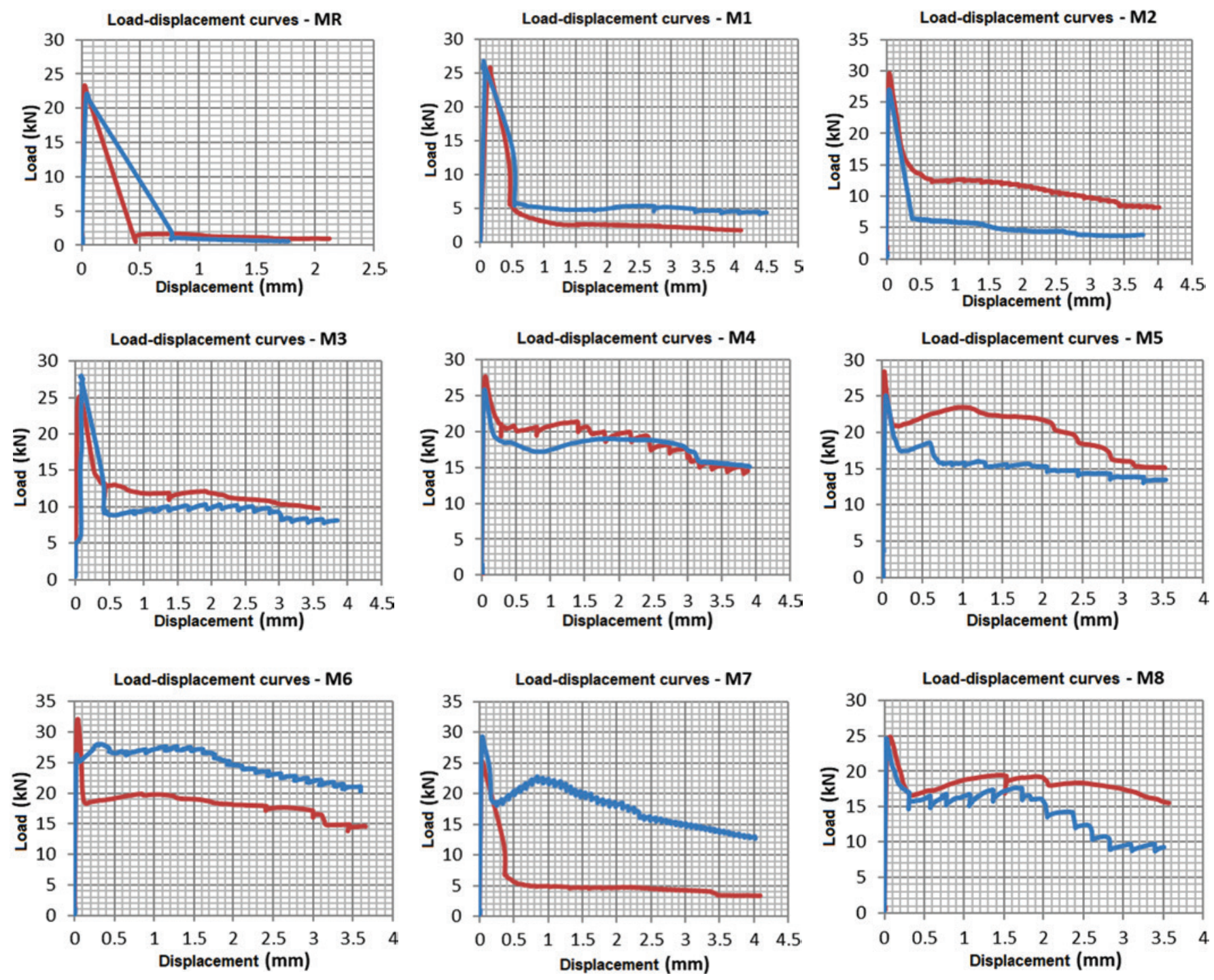

Figure 6

Load-displacement curves 


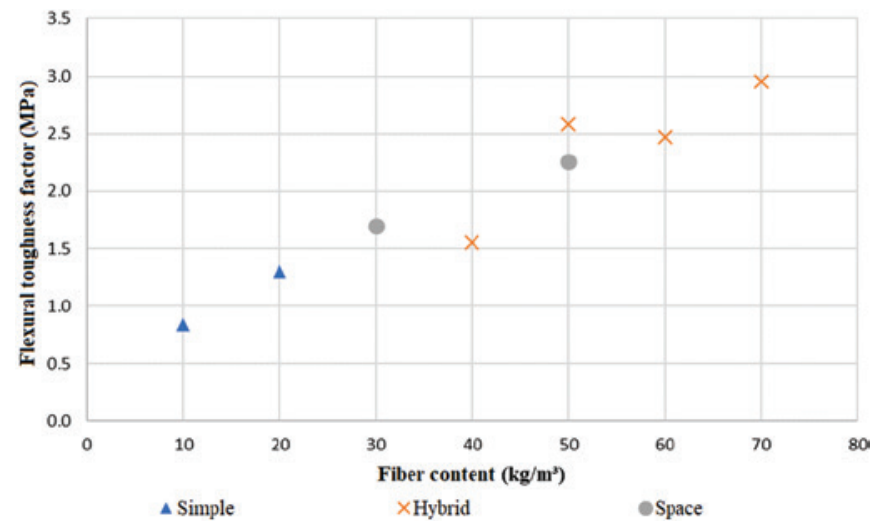

Figure 7

Increase of fiber content and flexural toughness factor

greater number of fibers that act on the fracture plane and, consequently, improve stress distribution, as Gil et al. [45] also identified. Another finding was that flexural toughness increased along with fiber content, as expected. Figure 7 depicts the correlation between flexural toughness factor and fiber content.

It shows a linear behavior that grows as the content of fibers increases, despite the discontinuity yielded by matrix $M 3\left(40 \mathrm{~kg} / \mathrm{m}^{3}\right)$. Finally, space fibers attained better values, although smaller than those of hybrid mixtures.

\section{Conclusions}

Based on the results and discussions of this study, it can be stated that adding space fibers to concrete has led to improvements to flexural strength and flexural toughness factor, despite the loss of workability and compressive strength. Matrix M4, a hybrid mixture with $30 \mathrm{~kg} / \mathrm{m}^{3}$ of space fibers and $20 \mathrm{~kg} / \mathrm{m}^{3}$ of simple fibers, achieved the best overall performance among the matrices that were tested, demonstrating the acceptable compatibility of this matrix with simple and space fiber contents.

\section{References}

[1] YOO, D.-Y. et al. Effect of fiber orientation on the ratedependent flexural behavior of ultra-high-performance fiber-reinforced concrete. Composite Structures, v. 157 p. 62-70, 1 dez. 2016.

QUININO, U. C. M. Investigação experimental das propriedades mecânicas de compósitos de concreto com adições híbridas de fibras. 2015. Thesis (Civil Engineering PhD) - Civil Engineering Graduate Program, Universidade Federal do Rio Grande do Sul (UFRGS), Porto Alegre, 2015. IBRAHIM, M. A. et al. Effect of Material Constituents on Mechanical and Fracture Mechanics Properties of UltraHigh-Performance Concrete. Materials Journal, v. 114, n. 3, p. 453- 465, 2017.

[4] FIGUEIREDO, A. D.; CECCATO, M. R. Workability Analysis of Steel Fiber Reinforced Concrete Using Slump and Ve-Be Test. Materials Research, 18 (2015), n. 6, pp. 1284-1290.
[5] EHRENBRING, H. Z. Comportamento de concreto reforçados com microfibras de polipropileno (PP), álcool polivinílico (PVA) e recicladas de poliéster ( $P O L)$ em relação à retração por secagem restringida e às propriedades mecânicas. 2017. 165 s. Thesis (Civil Engineering Master's) - Civil Engineering Graduate Program, Universidade do Vale do Rio dos Sinos, São Leopoldo, 2017.

[6] BENTUR, A.; MINDESS, S. Fibre reinforced cementitious composites. 2.Ed., Modern Concrete Technology Series, Taylor\&Francis, 2007.

[7] GÜNEYISI, E. et al. Combined effect of steel fiber and metakaolin incorporation on mechanical properties of concrete. Composites Part B: Engineering, v. 56, p. 83-91, 01 Jan. 2014.

[8] WU, Z. et al. Effects of steel fiber content and shape on mechanical properties of ultra high performance concrete. Construction and Building Materials, v. 103, p. 8-14, 30 Jan. 2016.

[9] YOO, D.-Y.; PARK, J.-J.; KIM, S.-W. Fiber pullout behavior of HPFRCC: Effects of matrix strength and fiber type. Composite Structures, v. 174, p. 263-276, 15 Aug. 2017.

[10] PARDINI, L. C. Preformas para compósitos estruturais. Polímeros, v. 10, n. 2, p. 100-109, June. 2000.

[11] RIBEIRO, J. L. P.; GREGORI, M. L.; PARDINI, L. C. Predição das propriedades elásticas de compósitos termoestruturais com reforço multidirecional. Matéria (Rio de Janeiro), v. 13, n. 1, p. 33-48, Mar. 2008.

[12] DU, Y. et al. Experimental study on basalt textile reinforced concrete under uniaxial tensile loading. Construction and Building Materials, v. 138, p. 88-100, 01 May 2017.

[13] WILLIAMS PORTAL, N.; NYHOLM THRANE, L.; LUNDGREN, K. Flexural behaviour of textile reinforced concrete composites: experimental and numerical evaluation. Materials and Structures, v. 50, n. 1, p. 1-14, Aug. 2017.

[14] COLOMBO, I. G. et al. Textile Reinforced Concrete: experimental investigation on design parameters. Materials and Structures, v. 46, n. 11, p. 1933-1951, 2013.

[15] BANTHIA, N. et al. Fiber synergy in Hybrid Fiber Reinforced Concrete (HyFRC) in flexure and direct shear. Cement and Concrete Composites, v. 48, p. 91-97, 01 Apr. 2014.

[16] BANTHIA, N.; SAPPAKITTIPAKORN, M. Toughness enhancement in steel fiber reinforced concrete through fiber hybridization. Cement and Concrete Research, v. 37, n. 9, p. 1366-1372, 01 Sept. 2007.

[17] TUTIKIAN, B. F.; HELENE, P. Dosagem dos concretos de cimento Portland. In: ISAIA, Geraldo Cechella. Concreto: Ciência e Tecnologia. São Paulo: IBRACON, 2011. Ch. 12. P. 415-452.

[18] BOULEKBACHE, B. et al. Flexural behaviour of steel fibrereinforced concrete under cyclic loading. Construction and Building Materials, v. 126, p. 253-262, 15 Nov. 2016.

[19] AMERICAN SOCIETY FOR TESTING AND MATERIALS. Standard Specification for Portland Cement. C150/ C150M, ASTM, Pennsylvania, 2018.

[20] AMERICAN SOCIETY FOR TESTING AND MATERIALS. Standard Test Method for Relative Density (Specific 
Gravity) and Absorption of Fine Aggregate. C128, ASTM, Pennsylvania, 2015.

[21] AMERICAN SOCIETY FOR TESTING AND MATERIALS. Standard Test Method for Bulk Density (“Unit Weight") and Voids in Aggregate. C29/C29M, ASTM, Pennsylvania, 2017.

[22] AMERICAN SOCIETY FOR TESTING AND MATERIALS. Standard Test Method for Relative Density (Specific Gravity) and Absorption of Coarse Aggregate. C127, ASTM, Pennsylvania, 2015.

[23] AMERICAN SOCIETY FOR TESTING AND MATERIALS. Standard Specification for Concrete Aggregates. C33/ C33M, ASTM, Pennsylvania, 2018.

[24] AMERICAN SOCIETY FOR TESTING AND MATERIALS. Standard Test Method for Sieve Analysis of Fine and Coarse Aggregates. C136/C136M, ASTM, Pennsylvania, 2014.

[25] FIGUEIREDO, A. D. Concreto reforçado com fibras. Thesis (habilitation) - Civil Construction Engineering Department, Escola Politécnica de São Paulo, São Paulo, 2011.

[26] ASSOCIAÇÃO BRASILEIRA DE NORMAS TÉCNICAS (ABNT). NBR 15530: Fibras de Aço para concreto. Rio de Janeiro, 2007.

[27] AMERICAN SOCIETY FOR TESTING AND MATERIALS. Standard Practice for Making and Curing Concrete Test Specimens in the Laboratory. C192/C192M, ASTM, Pennsylvania, 2016.

[28] JAPAN SOCIETY OF CIVIL ENGINEERS. Method of tests for flexural strength and flexural toughness of steel fiber reinforced concrete. JSCE-SF4. Concrete Library of JSCE. Part III-2 Method of tests for steel fiber reinforced concrete. № 3 June 1984. p.58-61.

[29] AMERICAN SOCIETY FOR TESTING AND MATERIALS. Standard Test Method for Slump of Hydraulic-Cement Concrete. C143/C143M, ASTM, Pennsylvania, 2015.

[30] AMERICAN CONCRETE INSTITUTE. Guide for Selecting Proportions for No-Slump Concrete (ACI 211.3R-02). ACI Committee 211. Detroit, USA, 2009.

[31] DEPARTAMENTO NACIONAL DE INFRA-ESTRUTURA DE TRANSPORTES. DIRETORIA DE PLANEJAMENTO E PESQUISA. INSTITUTO DE PESQUISAS RODOVIÁRIA. DNIT 064: Pavimento rígido - Determinação da consistência do concreto pelo consistômetro VeBe - Método de ensaio. Rio de Janeiro, 2004.

[32] AMERICAN SOCIETY FOR TESTING AND MATERIALS. Standard Test Method for Compressive Strength of Cylindrical Concrete Specimens. C39/C39M, ASTM, Pennsylvania, 2018.

[33] ABBASS, W.; KHAN, M. I.; MOURAD, S. Evaluation of mechanical properties of steel fiber reinforced concrete with different strengths of concrete. Construction and Building Materials, v. 168, p. 556-569, 2018.

[34] AKCAY, B.; TASDEMIR, M. A. Mechanical behaviour and fibre dispersion of hybrid steel fibre reinforced self-compacting concrete. Construction and Building Materials, v. 28, n. 1, p. 287-293, 2012.

[35] VELASCO, R.V. Concretos auto-adensáveis reforçados com elevadas frações volumétricas de fibras de aço: propriedades reológicas, físicas, mecânicas e térmicas. Thesis (Civil Engineering PhD) - Civil Engineering Graduate Program, Universidade Federal do Rio de Janeiro, Rio de Janeiro, 2008.

[36] TABATABAEIAN, M. et al. Experimental investigation on effects of hybrid fibers on rheological, mechanical, and durability properties of high-strength SCC. Construction and Building Materials, v. 147, p. 497-509, 2017.

[37] PRATHAP, P.; NARESH KUMAR, T.; NARAYANA, S. M. V. Evaluation of Mechanical Properties of Concrete using Silica fume and Steel fibers. International Journal of Scientific \& Engineering Research, v. 8, n. 5, p. 332-338, 2017.

[38] JANG, S. J.; YUN, H. D. Combined effects of steel fiber and coarse aggregate size on the compressive and flexural toughness of high-strength concrete. Composite Structures, v. 185, p. 203-211, 01 Feb. 2018.

[39] KHALOO, A. et al. Mechanical performance of self-compacting concrete reinforced with steel fibers. Construction and Building Materials, v. 51, p. 179-186, 31 Jan. 2014.

[40] LEE, J.-H.; CHO, B.; CHOI, E. Flexural capacity of fiber reinforced concrete with a consideration of concrete strength and fiber content. Construction and Building Materials, v. 138, p. 222-231, 01 May 2017.

[41] PAJĄK, M.; PONIKIEWSKI, T. Flexural behavior of selfcompacting concrete reinforced with different types of steel fibers. Construction and Building Materials, v. 47, p. 397-408, 01 Oct. 2013.

[42] EHRENBRING H. Z.; DE MEDEIROS QUININO, U. C.; OLIVEIRA, L. F. S.; TUTIKIAN, B. F. Experimental method for investigating the impact of the addition of polymer fibers on drying shrinkage and cracking of concrete. Structural Concrete, 2019; 20 pp. 1064-1075. https://doi. org/10.1002/suco.201800228

[43] PACHECO, F.; CHRIST, R.; GIL, A. M.; TUTIKIAN, B. F. Aplicação de MEV e microtomografia 3D na investigação da distribuição de fibras em compósitos cimentícios avançados. Rev. IBRACON Estrut. Mater., São Paulo, v. 9, n. 6, p. 824-841, Dec. 2016.

[44] CARRILLO, J.; CÁRDENAS PULIDO, J.; APERADOR, W. Flexural mechanical properties of steel fiber reinforced concrete under corrosive environments. Revista Ingeniería de Construcción, v. 32, n. 2, p. 59-72, 2017.

[45] GIL, A. M.; KHAYAT, K. H.; TUTIKIAN, B. F. An experimental approach to design self-consolidating concrete. Construction and Building Materials, v. 229, n. 30, 2019. https://doi.org/10.1016/j.conbuildmat.2019.116939 